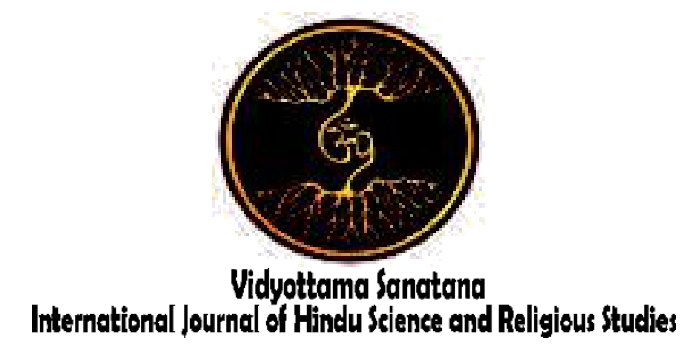

Vol. 2 No. 2 October 2018

\title{
Hindu Teacher Religion Learning Strategy In SMA Negeri 5 Denpasar
}

\author{
By: \\ Ni Made Sri Uttami Dharmaningsih ${ }^{1}$, I Ketut Tanu ${ }^{2}$, Ni Komang Sutriyanti ${ }^{3}$ \\ ${ }^{123}$ Institut Hindu Dharma Negeri Denpasar \\ E-mail: ${ }^{1}$ madesriuttami@gmail.com, ${ }^{2}$ ketuttanu@gmail.com, \\ ${ }^{3}$ nikomangsutriyanti@gmail.com
}

Received: August 10, 2018

Accepted: September 13, 2018

Published: October 31, 2018

\begin{abstract}
Technological developments and information flows add to the tendency of high rates of deviation by students. The responsibility of the school to further enhance its role through the teacher in providing moral education so as to form students' self-efficacy in behaving appropriately and improperly. Students' understanding of values can be formed through the learning process. The role of teachers, especially teachers of Hinduism, in implementing learning strategies is the main focus to be studied. Thus, through this study will be known learning strategies carried out by Hinduism teachers in anticipating student behavior and foster self-efficacy and instill educational values that characterize in Denpasar Public High School 5. Based on the above background, problems can be formulated as follows: Application of the Hindu religion teacher learning strategy in improving moral behavior and self-efficacy in Denpasar 5 SMA 2) Factors that influence the implementation of the Hindu religion teacher learning strategies in improving moral behavior and self-efficacy at SMA Negeri 5 Denpasar 3) Implications of the application of the learning strategy of Hindu religious education on moral behavior and self-efficacy in Denpasar SMA 5. This problem will be studied using Learning Theory, Constructivism Theory, and Stimulus Response Theory. Data collection techniques used: observation, interviews, documents, literature studies with the determination of informants using purposive sampling technique. Data analysis used is qualitative descriptive and triangulation. The results of this study are presented as follows: (1) Application of the Hindu religion teacher learning strategy using scientific learning strategies which include: (a) Implementation and Evaluation Planning; (b) Learning methods, media and learning resources used. (2) Factors that influence the implementation of Hindu religion teacher learning strategies include internal factors and external factors. Internal factors consist of (a) Teacher Factors; (b) Student Factors; (c)
\end{abstract}


School Management Factors; and (d) Learning Support Facilities and Infrastructure Factors. External factors consist of (a) social environment and (b) natural environment. (3) The implications of the implementation of learning strategies for Hindu religious education are (1) cognitive aspects, (2) affective aspects and (3) psychomotor aspects. Based on the description above, it can be concluded that the Hindu education learning strategy conducted at Denpasar Public High School 5 has its own method in its application, so it is able to control and overcome students from behavioral deviations and self-efficacy.

Keywords: Hindu Religion Learning and Leraning Strategy.

\section{Introduction}

Hinduism Education plays an important role in making Hindu students bersilila, so that later they can reach noble students who have sradha and bhakti. According to Wiana (1997: 19) the essence of Hinduism education is developing the use (talent) and self-sufficiency (nature, character, behavior, personality) that will make the child's identity concerned through three roles of students namely family, school, and community environment . Capitalize on competencies in accordance with selfconfidence (efficacy) and the child's motivation in the future to do swadharma optimally to achieve the life goals outlined by religion, namely the freedom of soul from samsara and free from worldly bonds and the law of karma phala. With the importance of moral education contained in religious teachings making religious subjects, in this case Hinduism should be prioritized and not ruled out among other subjects. This is evidenced by the research and appearance of samples of several junior high schools in the city of Denpasar contained in (hhtp: //cybertokoh.com/ Hindu Religion lessons are still in number two) downloaded on the steps of March 6, 2018 at 19.25 WITA. The results of this study are examples of a gap between reality and hope because in fact what is expected is the realization of noble character and not merely on cognitive alone.

The forms of deviant behavior that occur indicate evidence of a nation's moral decline. The existence of anarchism movements in several regions, inter-ethnic riots, inter-student brawls, alcoholism, and the use of illegal drugs to free sex among young people, gambling and places of prostitution that are difficult to eradicate, and so on. Indonesians experience various crises of confidence and confidence in themselves. The causes of these various crises began with the weak morality and morality of the nation.

Technological developments and information flow add to the tendency of high levels of deviation by students various phenomena occur in Denpasar State High School 5 as mentioned above can be caused by many things, for example the lack of understanding of Hindu teachings possessed by Hindu students, consider trivial learning of Hinduism, there are still many Hindu students who do not have the ethics of good manners, lack of confidence in themselves towards the ability to explore the learning of Hinduism, or the lack of creativity of teachers innovating in the implementation of Hindu learning. This phenomenon can still be tolerated as a form of deviation commonly practiced by students. It is the responsibility of the school to further enhance its role through the teacher in providing moral education so that there is a student's self-confidence (efficacy) that is inappropriate and improper to be carried out, especially in school in the community.

SMA Negeri 5 Denpasar has a large number of students, which is about 1211 people who are divided into 34 classes. While there are only 54 permanent teachers. Facing such a large number of students, of course there is a very visible gap between the ratio of students and teachers is not balanced. Such conditions generally tend to show students' uncontrolled behavior. Unlike the situation in this high school, student behavior can still be controlled. Even though there are students who do a number of behavioral irregularities, there is no one that goes beyond the level of tolerance or in a sense still can be considered a normal 
behavior. Conditions like this indicate that there is a strategy that is applied by the school or teacher in SMA Negeri 5 Denpasar dealing with a large number of students so that it remains in control.

\section{Method}

This research uses qualitative research, and uses two types of data (primary data and secondary data). In collecting data, purposive sampling is used to determine the informants. Data collection methods used are observation, interviews, documents, and literature. In the method of analysis the data obtained is classified and arranged systematically so that the results are presented in the form of narratives, the description is accompanied by arguments.

\section{RESULT and Disscusion \\ 3.1 General Description of Research Location}

This research was carried out at SMA Negeri 5 Denpasar. Related to the general description of the object of research will be described several things, as follows: 1) A Brief History of SMA Negeri 5 Denpasar, 2) Vision, Mission, and Insights of Wyatamandala SMA Negeri 5 Denpasar, 3) Location and Environmental Situation of SMA Negeri 5 Denpasar, 4) The state of teachers and employees of SMA Negeri 5 Denpasar, 5) The state of students of SMA Negeri 5 Denpasar.

\subsection{Application of Hinduism Teacher Learning Strategies in SMA Negeri 5 Denpasar}

Application of Hinduism Teacher Learning Strategies in SMA Negeri 5 Denpasar in terms of learning planning, implementation of learning, and evaluation of learning.

\subsubsection{Learning Planning}

Learning tools such as syllabus, lesson plans and teaching materials are arranged at the planning stage. All devices are designed so that the content and learning activities that will be carried out facilitate or have insight into character education that leads to the formation of self-efficacy and enhances the moral behavior of students in
SMA Negeri 5 Denpasar. the implementation of the learning process is an application of the syllabus and learning implementation plan (RPP) that has been compiled at the beginning of each lesson by the Hindu religious education subject teachers (MGMP) team. So that the learning carried out by Hindu religious education teachers to students at SMA Negeri 5 Denpasar is very concerned about the guidelines that will be used in material management activities and student learning activities.

Planning learning in Hinduism in the form of syllabus and lesson plans along with the Hindu religious education MGMP will produce a harmonious and harmonious agreement so that the concepts given can be well received by students. The RPP of Hindu religious education that is prepared also still refers to the content standard. Learning planning which is intended is the preparation of RPP activities, provision of media, learning resources, assessment tools and learning scenarios.

SMA Negeri 5 Denpasar in the student learning process is encouraged to develop 5 M namely: observing, asking, exploring, associating, and communicating so that students have self-confidence (efficacy) in developing creativity aspects (skills) as an innovation in character development (moral behavior). To carry out the learning process first the teacher must make changes in mindset, where the teacher should make preparations including preparation in terms of knowledge, physical preparation, mental preparation and heart to be able to carry out the task of educating sincerely.

\subsubsection{Implementation of Learning}

The implementation of Hinduism learning activities at SMA Negeri 5 Denpasar starts from the preliminary, core and closing activities. These steps are selected and carried out so that students can apply the values targeted in learning. Good classroom management from the teacher can help students achieve learning goals. The use of language and the selection of polite words also affect the form of classroom management. The principles of scientific learning are also applied by giving students 
self-efficacy towards all stages of learning while facilitating the process of internalizing values for students, in addition to the teacher's behavior throughout the learning process must provide values for students.

Preliminary activities of students at Denpasar Public High School 5 are always accustomed before starting the learning process, always beginning by saying the food greetings "Om Swastyastu" and greetings good morning or good afternoon together and thank you when learning is complete. Students are cultivated to be obliged to respect and say hello when meeting teachers, fellow students, and every older person.

The core and concluding activities in applying the Hindu learning strategy use the scientific approach. Students are facilitated to acquire knowledge, skills and develop attitudes through student-centered learning activities but in general remain guided by the tri concept rich in parisudha and the tri hita karana principle as the principle of moral character according to Hindu teachings, including in observing stages. Students are given the opportunity to seek and acquire further knowledge, skills and attitudes through learning resources and other learning activities so that the knowledge, skills and attitudes of students become broader and deeper, including in the stages of exploring, associating. The stage of communicating, students are given feedback on the truth and feasibility of the knowledge, skills and attitudes acquired by students. At the time of the implementation of the Hindu learning process, strategies that are applied are more directed towards learning activities that demand more student activity. Learning using media is based on e-learning as a learning process. Students are given the opportunity to find and find answers to the problems found in e-learning.

\subsubsection{Evaluation Learning}

Assessment of students of SMA Ngeri 5 Denpasar is done by using observation sheets that are based on basic values or standardization which are indicators of learning achievement, then further observations are made, to find out whether or not there is an increase in students' moral behavior. If there are students who are still having problems or in other words, do not experience improved behavior for the better, then in those students we do a persuasive approach.

Assessment in the process of learning Hinduism is carried out to determine the level of progress, setbacks and or difficulties faced by students in learning. This assessment will make it easier to make improvements and improvements in carrying out the learning process of Hinduism, for example, to find out how the progress experienced by students, must apply a rating system not only by assessing students at the end of learning but starting from the beginning of the learning until the end of the learning process. As for assessments carried out such as tests, tasks, skills in making upakara facilities, and students' attitudes in daily life. So that the assessment includes cognitive, affective, and psychomotor assessment.

\subsubsection{Applied Methods In Learning}

The education process carried out in schools generally uses methods that are oriented towards the achievement of the three educational domains that include cognitive, affective, and psychomotor to form character resources. The implementation of Hindu learning in SMA Negeri 5 Denpasar uses methods such as: lecture method, group discussion and work method, demonstration method, question and answer method, learning task method

\subsubsection{Media And Resources Used}

Learning media used by teachers in implementing Hinduism learning in SMA Negeri 5 Denpasar include: using LCD by displaying slide shows and filmstrips, using tape recorders such as accompanying music to do meditation exercises, chanting kidung and the like, using direct objects that are around students, such as paintings, ceremonial infrastructure made by students in the practice of upakara, using the surrounding environment, both natural conditions or interaction with school residents and the community.

Learning media is not only in the form of an intermediary in the form of television, radio, slides, modules but also includes people themselves who are involved 
in it. Learning resources can be in the form of books, teaching aids, resource persons such as teachers, writers and others. Learning resources in the form of environments such as museums, zoos, nature reserves. Learning resources have a very large function and role in teaching and learning activities, namely to provide opportunities for students to enrich the learning experience and add knowledge directly. Learning activities like this can stimulate motivation for students to learn because of the interactivity between students and existing learning resources.

\subsection{Factors Affecting Implementation of Learning Strategy Hindu Religious Teacher at SMA Negeri 5 Denpasar}

The implementation of Hindu religious education by implementing a learning strategy is influenced by various factors both internal and external, including the influence of the social and cultural environment of the community (Tanu, 2018: 118).

\subsubsection{Internal Factors}

Regarding the learning strategy of the Hindu religion teacher in Denpasar Denpasar State High School 5, there are several internal factors that influence, among others: 1) teacher factors, 2) student factors, 3) school management factors, and 4) learning supporting facilities and infrastructure factors.

\section{Teacher Factors}

The teacher is an important factor in implementing the curriculum into learning. The existence of the teacher is very decisive in the application of a learning strategy, because the teacher is a person who is dealing directly with students. The level of teacher's knowledge and insight that is less able to influence classroom learning. If the teacher is unskilled, unable to implement the curriculum properly, lacking the ability to relate the subject matter to the context of everyday life will have an impact on students' difficulties in capturing the intention of the teacher to convey through the material being taught. Thus, it will have an impact on the achievement of learning objectives.
A teacher is required to always develop his profession, always work, have a future insight to keep learning. Teacher's behavior in providing guidance is based on wisdom, compassion, and guided by conscience, so that being able to become a student experiences a change in behavior towards a better direction. Teachers through institutions such as schools, are responsible for forming characters and avoiding students from committing irregularities.

\section{Student Factors}

Students are unique organisms, developing according to the stages of development. Development in children includes all aspects of his personality, but with different rhythms and tempos in each child in each aspect of development in accordance with the formation of knowledge based on the students' own will. This is consistent with the constructivism theory where students actively build their own knowledge. Different children's development can influence the learning process, in addition to other characteristics inherent in the child.

\section{School Management Factors}

Hindu religious education is very much related to the management or management of SMA Negeri 5 Denpasar. The management is how Hindu religious education is planned, implemented and controlled in adequate school education activities. The management includes the values that need to be invested, the content in the curriculum, learning, assessment, educators, and other components related to it. Thus, school management is one of the effective media in improving students' moral behavior and self-efficacy through religious education and character.

\section{Learning Support Facilities and Infrastructure Factors \\ The programs for improving} education facilities and infrastructure carried out by SMA Negeri 5 Denpasar include the formulation of technical policy formulation of educational infrastructure facilities; preparation of programs and plans for procurement, distribution, utilization and maintenance of infrastructure; making infrastructure development proposals; 
preparation of procurement programs for textbooks and teaching materials or student learning modules;preparation of inventory items for procurement and removal needs; and create rehabilitation, renovation and replacement programs for learning materials or tools.

\subsubsection{External Factors}

Regarding the learning strategy of Hinduism teachers in SMA Negeri 5 Denpasar, there are several external factors that influence, among others: 1) social environment and 2) physical environment (natural).

\section{Social Environment Factors}

The family is the first place for each individual to learn and declares himself a social being in relation to family groups. The family consists of parents and children. Parents are the first and foremost source of education for children. Samudera (interview, 17 April 2018) said that parents really are the foundation of personality in children, because parents also play a role as educators. Then the basics of personality are useful and contribute to the influences or experiences that the child experiences later.

The life of a person and family cannot be separated from the surrounding environment. Between a person and the environment there is a mutually influential relationship. The development of each child is influenced by the surrounding environmental conditions. The environment is also influenced by individuals or groups in it. Therefore, a child's personality depends a lot on the condition of the environment in which he lives. So that society is the embodiment of human shared life because in it the process of social life takes place, the process between relationships and between actions.

\section{Natural Environmental Factors}

Teachers can use the surrounding natural environment as an alternative learning medium. This is done in an effort to prevent the emergence of a boring impression among students which is caused by the learning system implemented by the teacher, monotonically taking place in the classroom. Students can observe and record it for certain, changes that occur, including the process and so on through the natural environment. Learning will not feel boring if students are invited to interact with the learning environment, outside the classroom. Students can better understand the subject matter in school related to the surrounding nature, foster a sense of natural love, awareness and care to protect and preserve the environment, participate in tackling environmental damage and pollution and while maintaining the preservation of natural resources for life.

\subsection{Implications of Application of Hinduism Teacher Learning Strategies in SMA Negeri 5 Denpasar}

An understanding of broad and comprehensive religious teachings is an invaluable investment for students to improve learning achievement on cognitive, affective, and psychomotor aspects including sraddha and bhakti in a better future. Implications of the implementation of the Hindu religion teacher learning strategy in Denpasar 5 Public High School include three aspects of improving moral behavior and self-efficacy, namely: (1) cognitive aspects, (2) affective aspects, (3) psychomotor aspects.

\subsubsection{Cognitive Aspects}

Cognitive Aspect is an area that discusses learning objectives with a mental process that starts from the level of knowledge to a higher level, namely evaluation. This cognitive area consists of 6 (six) levels which are hierarchically sequential from the lowest (knowledge) to the highest (evaluation) (Uno, 2006:35). The implications of strategy forwarding include:

\section{Able to practice the teachings of loyalty}

The teachings of loyalty are grouped into five types which are more commonly referred to as Panca Satya. Loyalty in life is very important because with this loyalty, humans get a trust that not everyone has. Loyalty arises not from others, loyalty arises from within yourself. One example of the teachings of loyalty that is practiced by students of SMA Negeri 5 Denpasar, Satya Mitra, is an important part of this life. With a 
friend can share a little bit of grief, complain. A true friend will always be in all moods. So it needs loyalty to friends, where humans cannot live alone in this world. So students of SMA Negeri 5 Denpasar can understand each other with fellow friends both in the learning process and in completing tasks as a student.

\section{Able to Develop Tat Twam Asi Teachings}

Tat Twam Asi is a moral teaching that teaches Hinduism. The real form of this teaching can be observed in the life and daily behavior of the students concerned at school. Students in their lives have a variety of needs that are motivated by the wishes (kama) of the students concerned. Students are social living beings having their nature and variety, like humans as individual beings, social, religious, economic, cultural.

\section{Efforts to Improve Learning Outcomes}

Assessment of the learning process is an assessment of learning activities from the beginning to the end of the implementation of the learning process, such as an assessment of students' learning attitudes and activities in asking questions, discussing, expressing opinions, doing assignments, and demonstrating skills. While the assessment of learning outcomes is done after the end of the learning process to find out the students' knowledge and understanding of the concepts of the subject matter.

\subsubsection{Affective Aspects}

Affective aspects are domains related to attitudes and values. Affective aspects include behavioral characteristics such as feelings, interests, attitudes, emotions, and values. The implications of the implementation of learning strategies in SMA Negeri 5 Denpasar include:

\section{Increasing Student Religiosity}

Religiosity comes from the Latin "relegare" which means to increase closely or bond together. Religiosity is a person's spiritual expression related to the system of beliefs, values, applicable laws and rituals (Kaye \& Raghavan, in Thontowi, 2007: 1). Religiosity is generally explained related to cognition (religious knowledge, religious beliefs) that affect, what is done with emotional attachment or emotional feelings about religion, and or behavior, such as the presence at the Padmasana place when rahina purnama, tilem saraswati, reading the scriptures, and pray before starting or ending learning in class.

\section{Increased sense of love}

Through tat tvam asi teachings, students are taught to be good towards others so that other people will behave the same towards them. The teaching of tat tvam asi teaches mankind that in treating themselves. This teaching teaches about the reflection of human treatment. If humans hurt other people, then that means that humans hurt themselves. Mutual respect, respect, harmony in the different religions, nationalities and countries is what has always been developed in SMA Negeri 5 Denpasar, so that it can be called religious tolerance in schools. This attitude should be carried out by all citizens of the school, not only intended for students, but also includes principals, teachers, and employees to school committees.

Developing religious tolerance directly will have an impact on creating harmony with fellow human beings, with different backgrounds to achieve happiness. The development of religious tolerance in SMA Negeri 5 Denpasar appears in the behavior shown by the students. Schools provide opportunities for the creation of harmonization with fellow human beings, both among students, students towards teachers, between teachers, and / or between employees.

\section{Concern}

Caring for the environment is an attitude or action that always strives to prevent damage to the surrounding environment and strive for efforts to improve the damage done to nature. Environmental conservation efforts can be carried out by implementing a crop replanting program, especially in the school area of SMA Negeri 5 Denpasar. Our school is vigorously echoing and supporting the Adiwiyata program where SMANELA has won the Adiwiyata Mandiri school award by looking at various champions such as: shadow champions, green champions, beauty champions, shade champions, park 
champions, champions of natural balance and champions of environmental harmony.

\subsubsection{Psychomotor Aspects}

Psychomotor aspects include goals related to skills that are manual or motorized. Like the other two domains, this domain also has various levels. The sequence of levels from the simplest to the most complex (highest) is perception, readiness to carry out activities, mechanisms, guided responses, skills, adaptations, and organisms (Uno, 2006: 38). One of the training facilities for students in schools is extracurricular activities. Activities held in extracurricular programs are based on the objectives of the school curriculum. Through various extracurricular activities students can develop their skills, interests, and abilities in forming a full personality. Extracurricular activities carried out at SMA Negeri 5 Denpasar in order to develop the skills possessed by students to shape the full human character include: (1) Scouts, (2) Youth Red Cross, (3) Arts, (4) Sports, and (5) Academic Development.

\section{Conclusions}

1. The implementation of the Hindu religious education learning strategy at SMA Negeri 5 Denpasar uses scientific learning strategies which include: 1) planning from the preparation of RPP activities, provision of media, learning resources, assessment tools and learning scenarios 2) implementation emphasizing problem solving, directing students to become independent learners, encourage the creation of learning communities and pleasant learning situations 3) evaluation is done on attitude assessment, knowledge assessment, and skills assessment and 4) maximum learning methods and media in the process of learning activities that include the cultivation of spiritual attitudes, attitudes social, knowledge and skills in educating students in their entirety to improve student behavior and self-efficacy.

2. Factors that influence the implementation of the learning strategy of Hindu religion in SMA Negeri 5 Denpasar include internal factors and external factors. Internal factors that influence include: (1) teacher factors include being able to innovate in carrying out learning, using educational media, methodical and didactic skills, classroom management skills, educational evaluation skills, and skills to provide reinforcement and improve personal and professional competence, (2) student factors include interest, attention, intelligence or level of intelligence, talent, motivation, maturity, and readiness of students (3) school management factors include creating a systematic reporting system, creating a school management database, increasing awareness and community participation in education development through committees schools, and (4) factors supporting learning facilities and infrastructure include the provision of learning buildings, learning media, in the form of libraries, laboratories, and installing internet networks. While the external factors that influence are the environment. Environments that can be used as learning resources consist of: (1) social environment including family environment, community environment and (2) natural environment including geographical conditions, climate, air rates, seasons, rainfall, flora (plants), fauna (animals), natural resources.

3. Implications of the implementation of the Hindu education learning strategy in SMA Negeri 5 Denpasar with an understanding of religious and moral values that always underlie the principle of acting on tri teachings rich in parisudha, students are expected to be able to continue in the future and improve moral behavior and beliefs (selfefficacy) students, in the form of: (1) cognitive aspects including being able to practice the teachings of loyalty, being able to develop the teachings of Tat Twam Asi, efforts to improve learning outcomes (2) affective aspects include increased student religiosity, increased love, caring and (3) psychomotor aspects including scouting, arts, sports, academic development. 
References

Adia Wiratmaja. 1997, Etika Tata Susila Hindu Dharma. Jakarta: Sekjen PHDI Pusat.

Amri, Sofan. 2010.

Konstruksi Pengembangan Pembelajaran, Pengaruhnya Terhadap Mekanisme dan Praktik Kurikulum. Jakarta: Prestasi Pustaka.

Jadhav, D. (2018). On The Value Implied In The Data Referred To In The Mahābhārata for $\pi$. Vidyottama Sanatana: International Journal of Hindu Science and Religious Studies, 2(1), 18-38.

Perbowosari, H. (2018). Parenting Models In Building The Religious Characters of Children. Vidyottama Sanatana: International Journal of Hindu Science and Religious Studies, 2(1), $39-48$.
Sanjaya, Wina. 2012. Strategi Pembelajaran Berorientasi Standa Proses Pendidikan. Jakarta: Kencana. Smith, M. K. 2009. Teori Pembelajaran \& Pengajaran. Yogyakarta: Mirza Media Pustaka.

Tanu, I Ketut 2011. Pendidikan Agama Hindu di tengah Masyarakat Modernisasi. Denpasar: Yayasan Sari Kahyangan Indonesia.

Turner, Bryan S. 1991. Agama \& Teori Sosial:Rangka-Pikir Sosiologi dalam Membaca Eksistensi Tuhan di antara Gelegar Ideologi-ideologi Kontemporer. Yogyakarta:IRCiSoD.

Uno. 2006. Perencanaan Pembelajaran. Jakarta: PT Bumi Aksara. 